\section{OCEANOGRaphy In Practice}

$\mathrm{W}$ E PRACTICE OCEANOGRAPHY in many different ways. The ways vary from research that occurs in national institutes and military organizations to research practiced by scientists in universities and other organizations. Whatever our situation, I am sure we all often think "Is anyone going to use the knowledge gained from our studies?" It has been my observation that most of our knowledge affects govermental decisions very slowly. By slowly I mean years or decades. The slow process is one that goes something like this: field studies alternating with laboratory and theoretical studies, analysis and publication of results, synthesis and re-synthesis of insights, publication of reviews including new insights that are now becoming knowledge, publication in textbooks, use of the textbook by a student, the student graduating, joining a govermental organization, and, finally, the scientist making a decision based on the knowledge gained from the textbook.

Occasionally however something happens that, in its urgency, short circuits the normal process. The nuclear waste problems that are the focus of the Arctic Nuclear Waste Assessment Program are an example of an urgent problem needing quick acquisition of knowledge. The knowledge of the Arctic required to make good decisions was typical of oceanography-multidisciplinary. I hope the scientists that were involved in ANWAP enjoyed the great opportunity to apply their broad knowledge of oceanography to the Arctic nuclear waste issue and to see the information used quickly.

- Larry Atkinson

\section{Consider a feature article in Oceanography Contact the editors or associate editors}

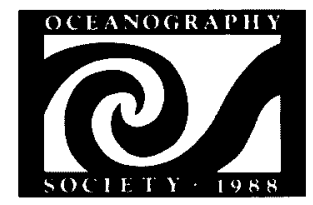

THE OCEANOGRAPHY SOCIETY

4052 Timber Ridge Drive Virginia Beach, VA 23455 USA

(757) 464-0131; fax: (757) 464-1759

OFFICERS

Robert A. Duce, President Kenneth Brink, President-Elect

Melbourne G. Briscoe, Secretary

David Evans, Treasurer

Margaret Leinen, Past-President

COUNSELORS

Ann Gargett

Larry Mayer

Bess Ward

Larry Atkinson

Kenneth Brink

Anthony Knap

Robert F. Anderson

Rick Spinrad

EXECUTIVE DIRECTOR

Judi Rhodes

CORPORATE/INSTITUTIONAL SPONSORS

Monterey Bay Aquarium Research Institute.

Pacific Grove, CA, USA

National Marine Fisheries Service,

Silver Spring. MD, USA

Ober, Kaler, Grimes \& Shriver

Washington, DC, USA

RD Instruments, San Diego, CA, USA

Scripps Institution of Oceanography,

La Jolla, CA, USA

\section{OCEANOGRaphy}

CO-EDITORS

Larry P. Atkinson

Center for Coastal Physical Oceanography

Old Dominion University

Crittenton Hall

Norfolk. VA 23529

(757) $683-5558$

Internet: atkinson@ccpo.odu.edu

Connie Sancetta

National Science Foundation

Ocean Sciences Division Room 725

4201 Wilson Blvd.

Arlington, VA 22230

(703) 306-1586

Internet: csancett@nsf.gov

ASSOCIATE EDITORS

James $W$. Ammerman

Department of Oceanography

Texas A\&M University

College Station, TX 77843 USA

(409) $845-5105$

Gregg J. Brunskill

Australian Institute of Marine Science

PMB No. 3, Townsville, M.C.

Queensland 4810 , Australia (077) 789 211; FAX (077) 725 852;

Internet: g_brunskill@aims.gov.au 